\title{
PEMBUATAN DAN UJI ORGANOLEPTIK SERBUK INSTAN MENTIMUN (Cucumis sativus L.) SEBAGAI ANTIHIPERTENSI DAN PENAMBAHAN JERUK NIPIS SEBAGAI RASA KHAS (Citrus aurantifolia)
}

\author{
Efi Anggraeni ${ }^{*}$, Agus Djamaluddin ${ }^{2}$, Dewi Ratnasari ${ }^{3}$ \\ ${ }_{123}$ Sekolah Tinggi Ilmu Kesehatan Holistik \\ *Korespondensi: Jl. Veteran, No. 272 Ciseureuh - Purwakarta. \\ Email: efianggraeninurjamil@gmail.com
}

\begin{abstract}
ABSTRAK
Latar belakang. Hipertensi atau tekanan darah tinggi tidak dapat dianggap penyakit yang ringan. Tidak hanya menurunkan kualitas hidup, namun dapat mengancam jiwa penderita. Ada dua terapi untuk hipertensi yaitu farmakologis dan non farmakologis. Pengobatan secara non farmakologi dapat dilakukan dengan Obat tradisional yang ada di Indonesia yang dapat digunakan sebagai alternatif pengobatan hipertensi adalah mentimun dan dapat dikombinasikan dengan jeruk nipis sebagai rasa penyegarnya.

Tujuan Penelitian. Penelitian ini bertujuan untuk mengetahui cara pembuatan sediaan instan dari mentimun dan jeruk nipis sebagai Anti Hipertensi alami, dan menentukan kestabilan sediaan serta menguji tingkat kesukaan terhadap sediaan yang dibuat.

Metode Penelitian. Penelitian ini menggunakan metode penelitian tindakan berupa perlakuan tunggal disusun dalam Rancangan Acak Lengkap (RAL). Perlakuan tunggal adalah dosis jeruk nipis yang terdiri dari 3 taraf yaitu sampel $A=$ penambahan jeruk nipis $3 \mathrm{ml}$, sampel $\mathrm{B}=$ penambahan jeruk nipis $6 \mathrm{ml}$, sampel $\mathrm{C}=$ penambahan jeruk nipis $9 \mathrm{ml}$.

Hasil Penelitian. Dalam pengujian organoleptik semua sediaan dapat bertahan selama tiga minggu dalam suhu ruangan $\left(20^{\circ}-25^{\circ} \mathrm{C}\right)$ kemudian dalam uji hedonik atau uji kesukaan sampel C yang paling banyak disukai yaitu 70,8\% dari 20 panelis.

Simpulan. Penambahan Jeruk nipis pada setiap sampel mempengaruhi rasa dan jumlah sediaan yang dihasilkan berbeda.
\end{abstract}

Kata kunci: Mentimun, jeruk nipis, serbuk instan

\begin{abstract}
Background. Hypertension or high blood pressure cannot be considered a mild disease. Not only does it reduce the quality of life, but it can be life threatening to sufferers. There are two therapies for hypertension, namely pharmacological and non-pharmacological. Nonpharmacological treatment can be done with traditional medicines in Indonesia that can be used as an alternative treatment for hypertension, namely cucumber and can be combined with lime as a refreshing taste. Then an instant powder preparation from cucumber and lime is made.

Purposes. This study aims to determine how to make instant preparations from cucumber and lime as natural anti-hypertension, and to determine the stability and to test the level of preference for the preparations made.

Research methods. This study used an action research method in the form of a single treatment arranged in a completely randomized design (CRD). Single treatment was the dose of lime which consisted of 3 levels, namely sample $A=$ addition of $3 \mathrm{ml}$ of lime, sample $B$ = addition of $6 \mathrm{ml}$ of lime, sample $C=$ addition of lime $9 \mathrm{ml}$.

Result. In organoleptic testing all preparations can last for three weeks at room temperature $\left(20^{\circ}-25^{\circ} \mathrm{C}\right)$ then in the hedonic test or preference test sample $C$ the most preferred is $70.8 \%$ of the 20 panelists.
\end{abstract}


Conclusion. The addition of lime to each sample affected the taste and the amount of preparation produced differently.

Key words: Cucumber, lime, instant powder

\section{PENDAHULUAN}

Jamu merupakan warisan budaya bangsa Indonesia, berupa ramuan bahan tumbuhan obat, sudah digunakan secara turun temurun yang terbukti aman dan mempunyai manfaat bagi kesehatan. Jamu dapat digunakan untuk menjaga kesehatan, kebugaran dan kecantikan serta dapat membantu pemulihan kesehatan dan pencegahan penyakit. Di Indonesia jamu biasanya digunakan masyarakat untuk kesehatan yang berasal dari bahan-bahan alam. Jamu juga dapat disebut obat rumahan karena biasanya dibuat sendiri di rumah dari bahan-bahan yang ada di sekitar. Sampai saat ini jamu masih menjadi ramuan yang dijaga kelestariannya sebagai kekayaan kearifan lokal, terutama di lingkungan Ciseureuh Kabupaten Purwakarta Jawa Barat

Hipertensi merupakan masalah kesehatan yang umum terjadi di masyarakat. Banyak orang yang menderita penyakit tersebut, tetapi tidak menyadarinya. Penyakit ini berjalan terus seumur hidup dan sering tanpa adanya keluhan yang khas selama sebelum ada komplikasi pada organ tubuh [3]. Kebiasaan masyarakat untuk mengontrol hipertensi adalah memakai pengobatan secara farmakologi dengan menggunakan obat-obatan sintetis, Selain itu pengobatan secara non farmakologi dapat dilakukan dengan Obat tradisional yang ada di Indonesia yang dapat digunakan sebagai alternatif pengobatan hipertensi adalah adalah mentimun (Cucumis sativus Linn), bawang putih, seledri, murbei, rosella, dan lain-lain (Wikipedia, 2010). Mentimun merupakan sayuran murah dan mudah di dapat sepanjang musim. Manfaatnya sangat beragam mulai dari sebagai obat alami, untuk kecantikan, bahkan untuk memberantas hama dan membersihkan rumah. Sebagai herbal antara lain untuk menyembuhkan hipertensi, detoks, pelangsing badan, atasi selulit, obat diare, sariawan, typhus, dan lain-lain. Mentimun banyak digunakan oleh masyarakat Indonesia seperti untuk lalaban, acar, penghias makanan, dan lain-lain. Mentimun bukan merupakan sesuatu hal yang asing bagi masyarakat Indonesia.

Mentimun mengandung banyak zat dan mineral yang sangat berguna untuk mengobati hipertensi [4][6]. Mentimun mengandung banyak mineral seperti potassium, kalium, natrium dan magnesium. Kandungan potasium bermanfaat untuk membersihkan karbon dioksida dalam darah, memicu kerja otot dan simpul saraf serta mengatur tekanan osmotik bersama natrium. Kandung mineral kalium, magnesium dan serat dalam mentimun bermanfaat untuk menurunkan tekanan darah. Mineral magnesium berperan melancarkan aliran darah dan menenangkan syaraf. Selain itu mentimun bersifat deuritic karena kandungan airnya yang tinggi sehingga membantu menurunkan tekanan darah. (Majalah nirmala dan rumah tani).

Salah satu tanaman yang dapat dikombinasikan dengan mentimun adalah jeruk nipis. Jeruk nipis memilki aroma kuat (asam) dan citarasa yang khas berasal dari asam sitrat yang terkandung didalam nya (Nour et al, 2010). Aroma dan rasanya sangat menyegarkan sehingga bisa dimanfaatkan sebagai bahan perisa alami untuk minuman. Air perasan jeruk nipis memiliki suasana asam dan aroma yang khas.

Jus mentimun efektif untuk menurunkan tekanan darah pada penderita hipertensi [2]. Pemberian jus mentimun dengan dosis 100 gram buah mentimun pada penderita hipertensi selama 7 hari dengan frekuensi 2 kali pemberian dalam sehari terbukti menurunkan tekanan darah [1]. Dengan demikian mentimun terbukti efektif untuk hipertensi, banyaknya orang yang menderita hipertensi menjadikan peneliti ingin mengembangkan mentimun menjadi sediaan yang mudah dikonsumsi, enak atau sedap dan tahan lama dengan tetap memperhatikan khasiat mentimun. 
Penelitian ini bertujuan untuk mengetahui cara pembuatan sediaan instan dari mentimun dan jeruk nipis sebagai Anti Hipertensi alami, dan menentukan kestabilan sediaan serta menguji tingkat kesukaan terhadap sediaan yang dibuat.

\section{METODELOGI PENELITIAN}

\section{Tempat dan Waktu Penelitian}

Penelitian ini dilaksanakan di Sekolah Tinggi Ilmu Kesehatan Holistik Purwakarta yang berada di Jl. Veteran No. 272, Desa Ciseureuh, Kecamatan Purwakarta, Kabupaten Purwakarta. Tempat ini dipilih dengan tersedianya peralatan yang dibutuhkan, dimulai dari pembuatan sediaan hingga pengamatan fisik sediaan serbuk mentimun (Cucumis sativus L.)sebagai antihipertensi dan penambahan jeruk nipis (Citrus aurantifolia).

Penelitian ini menggunakan metodelogi penelitian tindakan (action reseach). Penelitian tindakan merupakan salah satu pendekatan penelitian ilmiah yang memiliki dua tujuan yaitu mengambil tindakan dan membangun pengetahuan dan teori tentang tindakan. Penelitian tindakan memiliki siklus yang terus menerus yaitu perencanaan, pengambilan tindakan (pelaksanaan), dan evaluasi atas tindakan. Siklus ini terus berlanjut sampai ditemukan tindakan yang efektif dan efisien (Coghlan dan Brannick, 2010 ; Sugiyono, 2015). Dalam penelitian tindakan ini peneliti menerapkan perencanaan dari mulai menyiapkan bahan mentimun dan jeruk nipis, melakukan pelaksanaan pembuatan sediaan serbuk instan dengan menggunakan metode kristalisasi dan melakukan evaluasi atau tindakan pada sediaan yang sudah dibuat untuk menangani antihipertensi.

Penelitian ini merupakan pengembangan dan modifikasi dari penelitian sebelumnya, yang menyatakan bahwa jus mentimun efektif untuk menurunkan tekanan darah pada penderita hipertensi [2]. Dan penelitian lain menyatakan bahwa pemberian jus mentimun dengan dosis 100 gram buah mentimun pada penderita hipertensi selama 7 hari dengan frekuensi 2 kali pemberian dalam sehari terbukti menurunkan tekanan darah [1]. Pada penelitian sebelumnya bentuk sediaannya berupa jus, sedangkan untuk penelitian penulis mengganti menjadi bentuk sediaan serbuk instan. Pemilihan bahan utamanya yaitu mentimun yang ditambah dengan jeruk nipis sebagai rasa khasnya. Diharapkan penelitian ini mendapat formulasi yang tepat dari sediaan serbuk instan mentimun (Cucumis sativus L.) dan jeruk nipis (Citrus aurantifolia) sebagai antihipertensi.

\section{Prosedur Penelitian}

Penelitian ini dibagi menjadi dua tahap yaitu tahap pertama, proses pembuatan sedian serbuk instan dan tahap kedua, uji organoleptik. Adapun proses pembuatan sediaan serbuk instan mentimun (Cucumis sativus L.) dan jeruk nipis (Citrus aurantifolia) sebagai antihipertensi, Untuk kriteria mentimun dan jeruk nipis yang dipilih adalah yang masih segar, mentimun yang digunakan berwarna terang, memiliki tekstur yang keras ketika digenggam dan menghindari memilihi mentimun yang ujungnya telah berkerut peneliti menggunakan mentimun lokal, sedangkan jeruk nipis yang digunakan merupakan jeruk nipis key lime memiliki biji yang lebih banyak, lebih asam dan rasanya lebih kuat.

\section{Proses pembuatan sediaan serbuk instan}

Adapun proses pembuatan sediaan serbuk instan ini adalah:

1. Siapkan alat dan bahan

2. Cuci bersih mentimun dan jeruk nipis, pencucian ini bertujuan untuk membersihkan kotoran yang menempel pada bahan.

3. Sebanyak 200 gram mentimun dimasukan kedalam blender untuk diekstrak, kemudian dipisahkan antara filtrate dengan ampasnya menggunakan saringan.

4. Buat ekstrak jeruk nipis yang didapatkan dengan cara diperas menggunakan pemeras jeruk pisahkan dari bijinya dan ditambahkan saat ekstrak mentimun mengkristal.

5. Masukan kedalam wajan ekstrak mentimun kemudian dicampurkan 
dengan air dan gula pasir, lalu lakukan pemanasan dilakukan dengan suhu 60 - 65 C, dalam waktu kurang lebih 30 menit sambil terus diaduk dengan menggunakan spatula agar tidak menggumpal.

6. Pemanasan dilakukan hingga membentuk kristal.

7. Tambahkan sedikit demi sedikit hingga semua perasan jeruk nipis tercampur merata menjadi serbuk - serbuk halus. Penambahan jeruk nipis dilakukan di akhir agar minuman serbuk yang dihasilkan tidak menggumpaldan menjadi lengket.

8. Kemudian lakukan penghalusan dengan menggunakan blender. Penghalusan ini bertujuan untuk memperkecil ukuran minuman serbuk agar tidak menggumpal. Lalu diayak menggunakan ayakan agar serbuk memiliki kehalusan yang sama.

9. Serbuk yang sudah diayak diamkan sebentar agar uap panas dari proses pengayakan hilang.

10. Ulangi prosedur sebanyak tiga kali dengan kosentrasi jeruk nipis yang berbeda yaitu $3 \mathrm{ml}, 6 \mathrm{ml}, 9 \mathrm{ml}$.

11. Selanjutnya dikemas masukan kedalam wadah dan beri label.

Penulis membuat tiga formulasi dengan membedakan jumlah perasan jeruk nipis, agar didapat formulasi yang bagus setelah dilakukan uji organoleptik selama tiga minggu. Berikut formulasi sediaan serbuk instan mentimun dan jeruk nipis:

Tabel 1. Formulasi sediaan serbuk instan

\begin{tabular}{llll}
\hline Bahan & \multicolumn{2}{l}{ Formula } \\
\cline { 2 - 4 } & I & II & III \\
\hline $\begin{array}{l}\text { Sari mentimun } \\
\text { (Cucumis sativus } \text { L.) }\end{array}$ & $200 \mathrm{~g}$ & $200 \mathrm{~g}$ & $200 \mathrm{~g}$ \\
$\begin{array}{l}\text { Sari jeruk nipis } \\
\text { (Citrus aurantifolia) }\end{array}$ & $3 \mathrm{ml}$ & $6 \mathrm{ml}$ & $9 \mathrm{ml}$ \\
Gula pasir & $80 \mathrm{~g}$ & $80 \mathrm{~g}$ & $80 \mathrm{~g}$ \\
Air & $100 \mathrm{ml}$ & $100 \mathrm{ml}$ & $100 \mathrm{ml}$
\end{tabular}

\section{Parameter yang Diamati}

Parameter yang diamati pada penelitian pembuatan sediaan serbuk instan ini adalah uji organoleptik yang dilakukan selama tiga minggu. Uji organoleptik adalah mendeskripsikan sampel menggunakan pancaindera dalam hal tekstur, rasa dan aroma.

\section{Uji Organoleptik}

Uji Organoleptik atau uji indera atau uji sensori sendiri merupakan cara pengujian dengan menggunakan indera manusia. Uji organoleptik dilakukan selama 3 minggu dengan perbandingan komposisi penambahan jeruk nipis. Pengujian organoleptic sediaan yaitu mendeskripsikan warna, aroma, tekstur, dan rasa pada sediaan. Proses pengamatan dilakukan setiap 3 hari sekali.

\section{Uji Kesukaan}

Uji kesukaan juga disebut uji hedonik. Panelis dimintakan tanggapan pribadinya tentang kesukaan atau sebaliknya (ketidaksukaan)[7]. Disamping panelis mengemukakan tanggapan senang, suka 
atau kebalikannya, mereka juga mengemukakan tingkat kesukaannya.

Uji kesukaan yang meliputi rasa, warna, aroma, dan tekstur digunakan tingkatan kesukaan penelis terhadap sample dengan kriteria sebagai berikut :

Keterangan skala 1-5: 1 = Sangat Tidak Suka

$2=$ Tidak Suka

3 = Biasa-biasa Saja (Netral)

$4=$ Suka

5 = Sangat Suka

Dalam uji ini penilis diminta untuk mengisi form kuesioner uji kesukaan, penilaiannnya meliputi warna, aroma dan rasa. Penelis yang dipilih adalah penelis agak terlatih terdiri dari 15 orang disekitar rumah penulis yaitu di Jl.Veteran RT. 001 RW. 002 Desa Ciseureuh, Kecamatan Purwakarta, Kabupaten Purwakarta. Bagian yang digunakan adalah seluruh buah mentimun sedangkan untuk jeruk nipis yang digunakan adalah sari jeruk nipis. Tahap selanjutnya mentimun dibersihkan kemudian ditimbang dan di blender sedangkan jeruk nipis diperas diambil sarinya disiapkan sesuai jumlah yang diperlukan.

Tabel 2. Hasil pembuatan sediaan

\begin{tabular}{lcll}
\hline Sampel & Jeruk Nipis & Campuran bahan & Hasil \\
\hline A & $3 \mathrm{ml}$ & Sari Mentimun $100 \mathrm{ml}+$ air $100 \mathrm{ml}+$ gula 80 gram & 54 gram \\
B & $6 \mathrm{ml}$ & Sari Mentimun $100 \mathrm{ml}+$ air $100 \mathrm{ml}+$ gula 80 gram & 44 gram \\
C & $9 \mathrm{ml}$ & Sari Mentimun $100 \mathrm{ml}+$ air $100 \mathrm{ml}+$ gula 80 gram & 32 gram \\
\hline
\end{tabular}

Sediaan pun berbeda jumlahnya. Berdasarkan Tabel 2 di atas menunjukan hasil pembuatan sedian serbuk menghasilkan 3 sampel dengan jumlah yang berbeda. Jumlah sediaan tersebut sudah dipengaruhi oleh jeruk nipis dengan konsentrasi jeruk nipis pada masing-masing sampel berbeda kemudian pada proses pengambilan pada wajan sediaan masih ada yang menempel sehingga jumlah

\section{Hasil Uji Organoleptis}

Sediaan serbuk mentimun, jeruk nipis kemudian dilakukan pengujian organoleptis dengan mengamati rasa, aroma, tekstur sediaan selama 3 minggu diamati dalam tempo 3 hari sekali. Sediaan berupa 3 sampel di simpan dalam penyimpanan yang sama,yaitu dalam suhu ruangan $20^{\circ}-25^{\circ} \mathrm{C}$. Kemudian hasil pengamatan dicatat dalam bentuk Tabel dibawah ini. 
Tabel 3. Hasil Uji Organoleptis

\begin{tabular}{|c|c|c|c|c|c|c|c|c|c|}
\hline \multirow[t]{2}{*}{ Sampel } & \multirow[t]{2}{*}{ Pengamatan } & \multicolumn{8}{|c|}{ Hari Ke - } \\
\hline & & 1 & 3 & 6 & 9 & 12 & 15 & 18 & 21 \\
\hline \multirow[t]{6}{*}{ F1 } & Rasa & Tidak asam & Tidak asam & Tidak asam & Tidak asam & Tidak asam & Tidak asam & Tidak asam & Tidak asam \\
\hline & Aroma & Dominan & Dominan & Dominanm & Dominan & Dominan & Dominan & Dominan & Dominan \\
\hline & & mentimun & mentimun & entimun & & mentimun & mentimun & mentimun & \\
\hline & & & & & mentimun & & & & mentimun \\
\hline & Tekstur & Serbuk & Serbuk & Serbuk & Serbuk & Serbuk & Serbuk halus & Serbuk & Serbuk halus \\
\hline & & halus & halus & halus & halus & halus & & halus & \\
\hline \multirow[t]{5}{*}{ F2 } & Rasa & Kurang & Kurang & Kurang & Kurang & Kurang & Kurang asam & Kurang & Kurang asam \\
\hline & & asam & asam & asam & asam & asam & & asam & \\
\hline & Aroma & Sama rata & Sama rata & Sama rata & Sama rata & Sama rata & Sama rata & Sama rata & Sama rata \\
\hline & Tekstur & Serbuk & Serbuk & Serbuk & Serbuk & Serbuk & Serbuk halus & Serbuk & Serbuk halus \\
\hline & & halus & halus & halus & halus & halus & & halus & \\
\hline \multirow[t]{5}{*}{ F3 } & Rasa & Asam & Asam & Asam & Asam & Asam & Asam & Asam & Asam \\
\hline & Aroma & Dominan & Dominan & Dominan & Dominan & Dominan & Dominan & Dominan & Dominan \\
\hline & & jeruk nipis & jeruk nipis & jeruk nipis & jeruk nipis & jeruk nipis & jeruk nipis & jeruk nipis & jeruk nipis \\
\hline & Tekstur & Serbuk & Serbuk & Serbuk & Serbuk & Serbuk & Serbuk halus & Serbuk & Serbuk halus \\
\hline & & halus & halus & halus & halus & halus & & halus & \\
\hline
\end{tabular}


Berdasarkan hasil pengamatan yang tertera pada Tabel 3 menunjukan hasil uji organoleptik sediaan serbuk dari mentimun dan jeruk nipis yang telah diuji dan diamati selama 3 minggu, pengamatan dilakukan setiap 3 hari sekali. Pengamatan uji organoleptik meliputi rasa, aroma, tekstur sediaan. Data tersebut merupakan hasil pembuatan serbuk dengan metode kristalisasi yang dilakukan selama $3 \times 24$ jam. Pengamatan uji organoleptic dengan formulasi yang berbeda dalam suhu yang sama yaitu suhu ruangan $20^{\circ}-25^{\circ} \mathrm{C}$. Dapat dilihat dari hasil uji organoleptik sediaan yang telah dilakukan dan diamati selama 3 minggu tidak mengalami perubahan yang signifikan, sampai hari ke-21 ketiga sampel tersebut tidak menunjukan perubahan baik rasa, aroma, tekstur sediaan. Tidak terjadinya perubahan setelah uji organoleptik sesuai dengan tujuan dari pemanasan dalam suhu $60 \mathrm{C}$. Pengawetan dengan proses pemanasan ini memiliki cara kerja dengan membunuh organisme yang merugikan seperti bakteri, virus, protozoa, kapang dan khamir sehingga dapat memperpanjang daya simpan (Louis Pasteur, 1856).

Hal ini menunjukan bahwa sediaan serbuk instan dari mentimun dan jeruk nipis stabil dalam penyimpanan selama 3 minggu.

\section{Hasil Tingkat Kesukaan Konsumen Terhadap Serbuk Instan Mentimun dan Jeruk Nipis.}

Tabel 4. Hasil Uji Kesukaan

\begin{tabular}{ccccc}
\hline \multirow{2}{*}{ Jenis yang diuji } & Skor & \multicolumn{4}{c}{ Kode Sampel } \\
& & F1 (\%) & F2 (\%) & F3 (\%) \\
\hline \multirow{2}{*}{ Aroma } & Tidak suka & 60 & 25 & 20 \\
& Normal & 40 & 70 & 55 \\
& Suka & 0 & 5 & 10 \\
\multirow{2}{*}{ Rasa } & Tidak suka & 70 & 25 & 0 \\
& Normal & 30 & 75 & 40 \\
& Suka & 0 & 15 & 60 \\
\hline
\end{tabular}

\section{PEMBAHASAN}

Mentimun yang digunakan dalam penelitian ini diperoleh langsung dari pasar Rebo, Purwakarta. Proses pemilihan buah mentimun menggunakan mentimun yang berwarna terang, memiliki tekstur yang keras Ketika digenggam dan mengihindari memilih mentimun yang ujungnya telah berkerut. Kemudian potong - potong buah mentimun, serta meletakannya di wadah yang bersih. Mentimun yang telah diperoleh kemudian dibersihkan dengan air mengalir, pastikan semua debu dan kotoran yang menempel pada mentimun benar-benar bersih lalu tiriskan kedalam wadah.
Bahan kedua yaitu jeruk nipis yang diperoleh langsung dari pasar Rebo, Purwakarta. Setelah diperoleh jeruk nipis dibersihkan dengan air mengalir. Kemudian jeruk nipis diperas menggunakan perasan jeruk pisahkan dari bijinya.

Setelah bahan utama terkumpul selanjutnya masuk ke tahap pembuatan serbuk instan. Dalam pembuatan ini mentimun ditimbang 200 gram kemudian di blender lalu dipisahkan antara filtrate dengan ampasnya menggunakan saringan, didapatkan filtrate mentimun sebanyak 100 ml, tambahkan air sebanyak $100 \mathrm{ml}$ dan gula sebanyak 80 gram kemudian terakhir 
masukan perasan jeruk nipis dengan kosentrasi yang berbeda.

Dalam pembuatan sediaan instan mentimun dan jeruk nipis dilakukan dengan cara penggodokan sampai mengkristal. Pada saat pembuatan dilakukan agar terus diaduk dalam wajan dengan api kecil agar sediaan tidak mudah gosong dan tetap stabil sampai menjadi serbuk. Hasil sediaan instan yang didapat dari ketiga sampel $\mathrm{A}$ jeruk nipis $3 \mathrm{ml}$, sampel B jeruk nipis $6 \mathrm{ml}$, dan sampel $C$ jeruk nipis $9 \mathrm{ml}$ mendapat hasil akhir yaitu sampel A 54 gram, B 44 gram, C 32 gram.

Tahap selanjutnya pengujian organoleptik selama 3 minggu dengan tujuan untuk menguji kestabilan sediaan dan memastikan tidak terjadinya perubahan tekstur, warna, dan rasa. Pengujian dilakukan dengan menyimpan di suhu ruangan. Hasil yang didapat selama 3 minggu pada suhu ruangan yaitu $20^{\circ}-25^{\circ} \mathrm{C}$ bahwa tidak adanya perubahan dalam tekstur, aroma dan rasa. Sediaan yang mempunyai kualitas dan ketahanan yang lebih baik ialah yang di simpan pada suhu ruangan yaitu berkisar $20^{\circ}-25^{\circ} \mathrm{C}$.

Pada uji kesukaan atau uji hedonik peneliti memilih 20 panelis untuk menilai dari ketiga sampel tersebut ditinjau dari aroma, dan rasa. Panelis diminta untuk mencoba suatu ketiga sampel dan mengamati secara organoleptik, kemudian setelah itu panelis diminta untuk memberikan tanggapan dan penilaian atas sampel yang dicoba tersebut tanpa membandingkannya dengan yang lain. Kemudian panelis menganalisis ketiga sampel sediaan instan tersebut dan memberikan penilaian terhadap rasa suka atau ketidaksukaannya dengan menggunakan skala hedonik berupa skala kategorik sesuai tingkat kesukaannya. Skala hedonik yang digunakan adalah 1 : sangat tidak suka, 2 : tidak suka, 3 : netral, 4 : suka, 5 : sangat suka. Tujuan dari uji hedonik ini untuk mengetahui tingkat kesukaan konsumen terhadap produk dan untuk menilai komoditi jenis atau produk pengembangan secara organoleptik.

Pada uji hedonik atau uji kesukaan dari ke tiga formula peneliti memilih formula C $100 \mathrm{ml}$ jus mentimun, $100 \mathrm{ml}$ air, gula 80 gram dan perasan jeruk nipis $9 \mathrm{ml}$ menghasilkan sediaan akhir sebanyak 32 gram dengan alasan bahwa sediaan ini mempunyai rasa yang tidak terlalu manis dan juga asam serta paling disukai diantara formula A dan formula B.

Penelitian ini merupakan suatu penelitian pengembangan yang berupa pembuatan ramuan sediaan instan dari bahan herbal yang diperuntukan untuk mengatasi tekanan darah tinggi [5]. Bahan herbal yang digunakan yaitu mentimun dan jeruk nipis yang dibuat kedalam bentuk sediaan serbuk instan yang dapat diminum dengan cara diseduh yang penggunaannya sangat praktis.

\section{KESIMPULAN}

Dari hasil pengujian organoleptik dihasilkan tiga sediaan dengan rasa yang sedikit berbeda salah satunya memiliki rasa yang cukup enak yaitu tidak terlalu asam serta tidak terlalu manis. Serbuk instan yang memiliki ketahanan yang cukup lama dan stabil yaitu yang di simpan pada suhu ruangan $\left(20^{\circ}-25^{\circ}\right)$ Pengujian hedonik tiga formula yang telah dilakukan diketahui bahwa formula $\mathrm{C}$ lebih banyak disukai panelis dari segi rasa, bentuk, dan aroma. Sediaan serbuk instan ini dibuat sebagai minuman untuk menurunkan hipertensi dengan konsentrasi jus mentimun $100 \mathrm{ml}$, jeruk nipis $9 \mathrm{ml}$, gula 80 gram, dan air 100 $\mathrm{ml}$.

\section{DAFTAR PUSTAKA}

1. Aisyah, A., \& Probosari, E. (2014). Pengaruh Pemberian Jus Mentimun (Cucumis Sativus L) terhadap Penurunan Tekanan Darah pada Penderita Hipertensi Wanita Usia 40-60 tahun (Doctoral dissertation, Diponegoro University).

2. Saeful Nurhidayat (__ $)$. Perilaku Masyarakat Desa sebagai Faktor Resiko Penyakit Hipertensi. Universitas Muhamddiyah Ponorogo.

3. Yudini. (2006). Faktor Resiko Hipertensi dan pengendalian penyakit menular. PT Gramedia. Jakarta

4. Elliya, R., Hermawan, D., \& Trismiana, E. (2016). Pengaruh Jus Mentimun 
(CUCUMIS SATIVUS) Terhadap Penurunan Tekanan Darah Pada Penderita Hipertensi di UPD Panti Sosial Lanjut Usia TResna WErha Kecamatan Natar Kabupaten Lampung Selatan Tahun 2015. Holistik Jurnal Kesehatan, 10(1), 27-31.

5. Kharisna, D., Dewi, W. N., \& Lestari, W. (2012). Efektifitas konsumsi jus mentimun terhadap penurunan tekanan darah pada pasien hipertensi. Jurnal Ners Indonesia, 2(2), 124-131.

6. Ningsih, W. W. (2015). Pengaruh Pemberian Jus Mentimun Terhadap Penurun Tekan Darah Pada Penderita Hipertensi Di Desa Sawah Porong Sidoarjo. Skripsi Keperawatan.

7. Rahardjo (1998). BAB, I. Uji Penerimaan (Uji Hedonik dan Uji Mutu Hedonik) 